\title{
Recent updates for biomaterials used in total hip arthroplasty
}

\author{
Chang Yong Hu and Taek-Rim Yoon
}

\begin{abstract}
Background: Total hip arthroplasty (THA) is probably one of the most successful surgical interventions performed in medicine. Through the revolution of hip arthroplasty by principles of low friction arthroplasty was introduced by Sir John Charnley in 1960s. Thereafter, new bearing materials, fixation methods, and new designs has been improved. The main concern regarding failure of THA has been the biological response to particulate polyethylene debris generated by conventional metal on polyethylene bearing surfaces leading to osteolysis and aseptic loosening of the prosthesis. To resolve these problems, the materials of the modern THA were developed since then.

Methods: A literature search strategy was conducted using various search terms in PUBMED. The highest quality articles that met the inclusion criteria and best answered the topics of focus of this review were selected. Key search terms included 'total hip arthroplasty', 'biomaterials', 'stainless steel', 'cobalt-chromium', 'titanium', 'polyethylene', and 'ceramic'.

Results: The initial search retrieved 6921 articles. Thirty-two articles were selected and used in the review.

Conclusion: This article introduces biomaterials used in THA and discusses various bearing materials in currentclinical use in THA as well as the newer biomaterials which may even further decrease wear and improve THA survivorship.
\end{abstract}

Keywords: Hip, Arthroplasty, Biomaterials, Stainless steel, Cobalt-chromium alloy, Titanium alloy, Polyethylene, Ceramic

\section{Background}

Total hip arthroplasty (THA) is one of the most popular surgical procedures performed worldwide. In England, the National Joint Registry recorded that more than 790,000 THAs were performed between 2003 and 2015 [1]. As of 2003, more than 200,000 THA operations were performed annually in the USA, about 2.5 million people are living with a hip replacement [2]. This number is expected to reach 572,000 by 2030 [3]. In Korea, the Health Insurance Review and Assessment Service informed that more than 60,000 THAs were performed between 2010 and 2017, and incidence was increasing over time [4].

Current developments in the field of artificial hip joints are focused on mechanical strength, biocompatibility [5-8], bioactivity [9-18] and materials that impart better wear resistance and mechanical reliability [19-28]. When an implant fails, patients may endure severe pain and disability and require revision surgery. Periprosthetic osteolysis is the

\footnotetext{
* Correspondence: tryoon@chonnam.ac.kr

Center for Joint Disease, Chonnam National University Hwasun Hospital, 160, Ilsim-Ri, Hwasun-Eup, Hwasun-Gun, Jeonnam 519-809, South Korea
}

primary cause of failure that is the result of activation of an innate immune response caused by wear of bearing materials in THA. Taken up by macrophages and multinucleated giant cells, the presence of wear debris particles may cause the release of cytokines, thereby resulting in inflammation that further activates osteoclasts and finally leading to implant loosening.

The functional goal of joint arthroplasty is to return a patient to activities of daily living and range of motion in the absence of pain. Thus, various biomaterials have been used and are constantly being developed. The purpose of this review was to provide an update on the development status of various materials in THA.

\section{History of development of Total hip arthroplasty}

Metal on metal (MoM) bearings were made using large ball diameters during 1955-1965 [29]. However, the use of MoM bearings declined in the 1970s for some years after Sir John Charnley introduced a THA device based on metal on polyethylene (MoP) composed of a small metal ball and a cemented polyethylene (PE) cup in a 1960s [30]. Long term survival of these early implants 
was good, with around $77-81 \%$ of success rate 25 years after primary THA [31]. With the increasing use of THA in younger and more active patients, the revision rate becomes higher [32], and there has been concerns about the role of PE wear particles in osteolysis and loosening [31]. New materials have been introduced to prevent wear and osteolysis.

Pierre Boutin, a French surgeon who anticipated the problem of "polyethylene disease", began using alumina ceramic on ceramic (CoC) hip implants in a 1970s [33]. $\mathrm{CoC}$ implants have been used in THA and these developments also created ceramic on polyethylene (CoP) combinations as competitive bearing alternative along with MoM and CoC over 1963-1973 (Fig. 1).

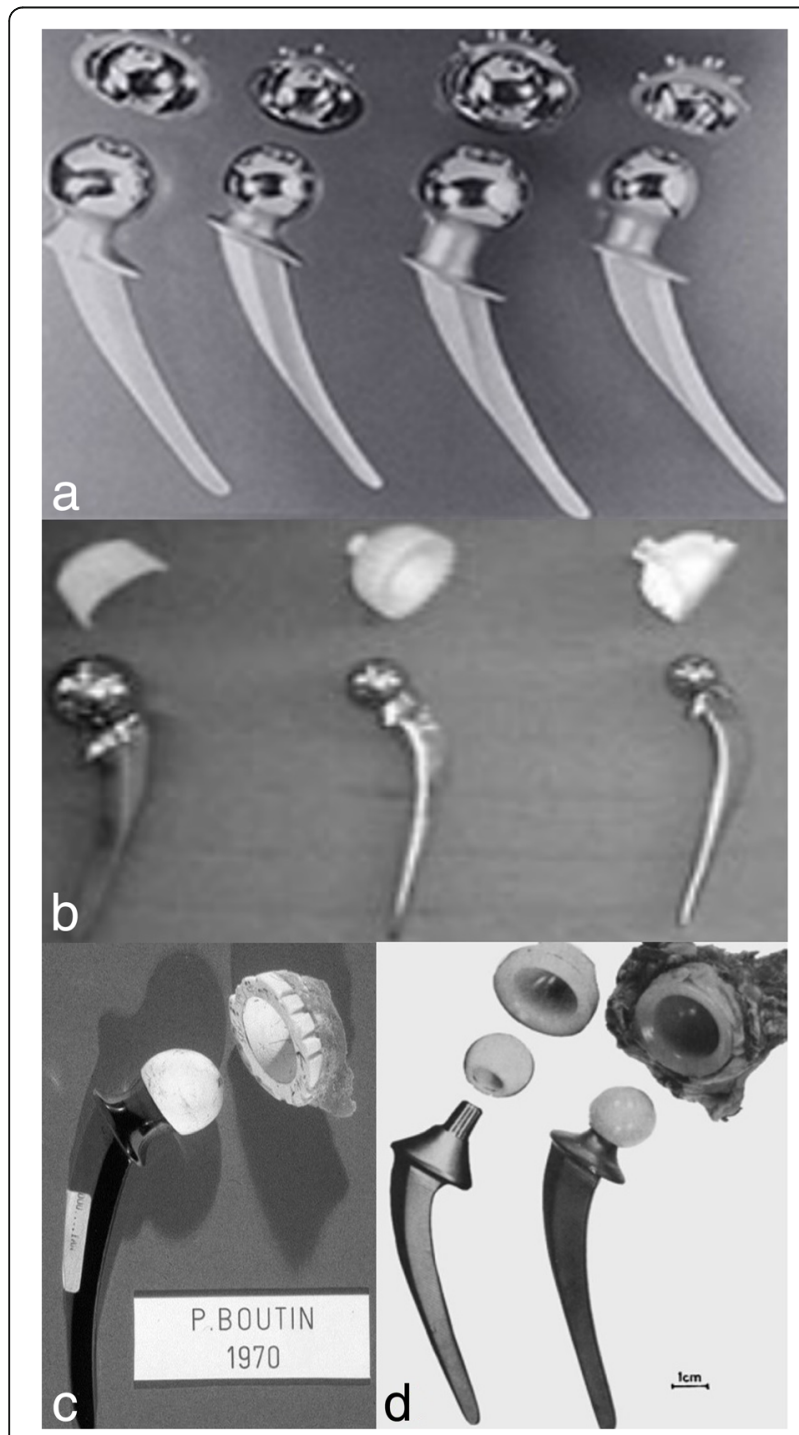

Fig. 1 Early bearing materials used in THA (a) MoM Mckee-Farrer THA from 1960 (b) MoP combinations, Thompson prosthesis in a 1960s (c) CoC hip implants in a 1970s (d) CoP combinations over 1963-1973
Stainless steel was the first class of alloy introduced for orthopedic implants [34]. However, since some corrosion was inevitable, it has been recommended that stainless steel only be used for short duration purposes [35]. Currently, the most frequently used artificial hip joints are composed of an acetabular cup, liner, head and stem. The main materials for THAs were titanium, cobalt-chromium, PE, and ceramic, respectively.

\section{Supporting metallic materials}

\section{Stainless steel}

Stainless steels are iron-carbon based alloys. In general, these alloys contain $\mathrm{Cr}, \mathrm{Ni}, \mathrm{Mo}, \mathrm{Mn}$ and $\mathrm{C}$. The austenitic (316 series) alloys are typically used in fracture-fixation devices. The resistance to oxidation coupled with relative ease of machining, forming, and hardening makes stainless steel a strong candidate for material choice. Stainless steel is rarely used for THA material nowadays, because of poor biocompatibility, though stainless steel devices remain available in other countries (particularly the United Kingdom).

\section{Cobalt-chromium (co-Cr) alloys}

$\mathrm{Co}-\mathrm{Cr}$ alloys which was used in dentistry, are now one of the major materials used for hip prostheses. The favorable strength, corrosion, and wear characteristics make alloys of $\mathrm{Co}-\mathrm{Cr}$ one of the main choice as an implant material. It is mainly used as cement type femoral stem material because the Young's modulus is larger than titanium alloys and articulating head due to wear resistance.

\section{Titanium alloys}

Titanium and its alloys are popular metallic implant biomaterials used in THA. Commercially, $\alpha+\beta$ titanium alloys, such as titanium-6Al-4 $\mathrm{V}$ have been the most commonly used alloys for stem and acetabular cementless components of THA, because of its comparatively low density, high mechanical strength, excellent corrosion resistance, and biocompatibility with bone [36].

However, Titanium alloys are not used for manufacturing of femoral head due to their poor wear resistance.

During the last two decades, vanadium free titanium alloys such as $\alpha+\beta$ titanium-6Al-7Nb alloy with improved biocompatibility have been developed by incorporating biocompatible elements such as Niobium [5-8]. Many researches have been devoted to the development of bulk metallic materials that have lower Young's modulus, among which $\beta$ titanium alloys have attracted significant attention.

\section{Alloy surface modifications}

Classic implants are fabricated using traditional materials (sintered beads, fiber metal, plasma spray) which have several inherent biomaterial limitations. In order to achieve an effective osseointegration with a vital bone 
implant contact and reduce risk of loosening, the use of porous metals andcoatingswere developed [37]. In general, compared to stainless steels and Co-Cr alloys, titanium, some of its alloys and tantalum are the more suitable porous metallic materials used for orthopaedic applications.

Hydroxyapatite has been used in order to achieve the permanent mechanical fixation of an implant in the bone bed to involve the process of osseointegration [38]. Porous metal has been also introduced to obtain biological fixation and improve longevity of orthopedic implants [39]. The new generation of porous metal has intriguing characteristics that allows bone healing and high osteointegration of the metallic implants [40].

\section{Materials used in bearing surface Polyethylene UltraHigh molecular weight polyethylene (UHMWPE)} UHMWPE was first introduced in 1962 as the bearing for the Charnley hip prosthesis. He developed the low-friction arthroplasty consisting of cemented fixation with a bearing surface of a $22.25-\mathrm{mm}$ metallic femoral head andan all-PE cup [41].

Conventional PE is sterilized by gamma irradiation in air. This process offers the benefits of molecular crosslinking but can also produce free radicals that is oxidized in the presence of air [42]. Oxidation decreases resistance of the biomaterial, resulting in degradation and brittle PE, and thus may increase wear [43]. PE wear is multifactorial: among the different factors associated with wear are a patient's higher activity level, a big femoral-head diameter or thin PE liners, vertical orientation of the acetabular cup, or the use of modular uncemented cups [44, 45]. UHMWPE wear debris mediated osteolysis is widely recognized as one of the most serious challenges in hip arthroplasty [46, 47].

\section{High crosslinked UHMWPE (XLPE)}

The developmentof new XLPE is aimed at improving UHMWPE in both cemented and uncemented implants. In order to decrease PE wear, research has attempted to improve wear resistance while maintaining mechanical properties and eliminating the oxidation process [48].

Crosslinking is accomplished by using either gamma radiation or electron beam radiation to break the molecular bonds. All manufacturers produce XLPE based on three processes: crosslinking, heat treatment, and sterilization while avoiding exposure to air. Higher crosslinking density is obtained using gamma irradiation or electron beams at a dose between 50 and $100 \mathrm{kGy}$ to increase wear resistance. Heat treatment is aimed at eliminating free radicals that appear after crosslinking; this thermal treatment applies temperature above (remelting) or below (annealing) the melting transition temperature of the polymer $\left(137^{\circ} \mathrm{C}\right)$.
In vivo studies, Manning et al. reported $95 \%$ wear rate reduction, and Martell et al. showed $42 \%$ to $50 \%$ wear rate reduction using XLPE compared to conventional PE [49, 50]. Biologic activity of the wear debris was also reduced and osteolysis has been dramatically decreased [49-54].

\section{Antioxidant doped polyethylene}

In efforts to improve oxidation resistance without compromising mechanical properties through thermal treatments, XLPE is stabilized by the addition of antioxidants like vitamin $\mathrm{E}$, to prevent oxidation of free radicals with the intention of increased wear resistance $[19,20,55]$. Although initial results are promising, longterm clinical results of this second generation PEs are not yet available.

\section{Poly (2-methacryloyloxyethyl phosphorylcholine) (PMPC)}

Kyomoto et al. made a great progress in tribological aspect of XLPE [21]. XLPE has been surface-treated on the articulating surface, covering the surface with a chemically thin layer (100-200 $\mathrm{nm}$ ) to improve abrasion resistance. Poly (2-methacryloyloxyethyl phosphorylcholine) (PMPC), which is formed by photo-induced graft polymerization, creates a super-lubricious layer that mimicks articular cartilage [22]. A recent hip simulator study reported that MPC polymer grafted on the XLPE surface dramatically reduced the wear up to 70 million cycles [56].

\section{Ceramics}

\section{Alumina}

Alumina has been used as a bearing surface in total hips since the 1970s [57]. Alumina ceramics have biocompatibility, high wear resistance, and chemical durability. Wear was as low as a few microns for a 15 -year period in use, which is 2000 times less than a regular MoP sliding couple and 100 times less than a MoM prosthesis [58].

Although alumina ceramics have shown better wear characteristics than MoP, alumina has historically had a high incidence of fracture [59]. This high incidence of fracture led to improved manufacturing processes which was possible by decreasing grainsize and porosity, and by tempering process for the increase of toughness [60].

With the improvements made in alumina material properties, the incidence of fracture has declined dramatically in recent years. The decreased incidence of fracturing of alumina components has made ceramics a more feasible option, especially for younger, more active patients [59].

\section{Zirconia}

Zirconia femoral heads were introduced in Europe in 1985 and later introduced into the USA in 1989 [61]. The move from alumina to zirconia as a femoral head component was because of the high incidence of fractures of alumina heads and the increased fracture toughness of zirconia compared 
to alumina [62]. Zirconia also had a historically higher bending strength than alumina [63].

However, in view of the recently reported potential for zirconia ceramics to undergo monoclinic phase transformation in vivo, with resultant increased fracture risk and degradation of wear properties [64, 65]. Unfortunately, the largest manufacturer of zirconia femoral heads recalled their products in 2001, because of problems with the thermal processing associated with those batches [61]. Since the recall, use of zirconia stabilized with yttria has declined, but a trend toward developing alumina-zirconia composites to improve performance of ceramic bearings has emerged [66].

\section{Alumina-zirconia composites}

Despite the long clinical history of alumina and zirconia in THA, both materials had drawbacks. Attempts to overcome the weaknesses of these materials by combining alumina's hardness with zirconia's toughness have led to the development of zirconia-toughened alumina (ZTA), which was first commercialized by CeramTec under the trade name of BIOLOX $^{\odot}$ Delta in around 2000. ZTA is an alumina matrix composite containing $75 \%$ fine grained alumina of $0.5-0.6 \mu \mathrm{m}$ in diameter and $25 \%$ Y-TZP with a grain size of $1 \mu \mathrm{m}$ or smaller to obtain a flexural strength of $1200 \mathrm{MPa}$ and a fracture toughness of $6.5 \mathrm{MPa} \sqrt{\mathrm{m}}$ [66]. The base alumina matrix ensures high hardness of the materials, and the addition of zirconia particles promotes resistance to crack propagation [62]. ZTA also slows down the kinetics of hydrothermal aging, which is a potential advantage over monolithic zirconia.

\section{Silicon nitride}

Silicon nitride is a non-oxide ceramic material with high strength and toughness and has been used as bearings, turbine blades for more than 50 years. In the medical field, since 2008, it has been used in cervical spacer and spinal fusion devices, with few adverse reports among 25,000 implanted spinal cages [67, 68]. Silicon Nitride has been recently regarded as a bearing material for artificial hips due to its high biocompatibility, moderate Vickers hardness of 12-13 GPa, Young's modulus of $300 \mathrm{GPa}$, high fracture toughness of 10-12 $\mathrm{MPa} \sqrt{\mathrm{m}}$ and flexural strength of $1 \mathrm{GPa}$, with a typical grain size of $0.6 \mu \mathrm{m}$ after alloying with small amounts of yttria and alumina [69]. Mechanical testing has shown higher fracturetoughness, higher flexural strength, higher resistance to hydrothermal degradation. Biocompatibility tests haveshown that Si3N4 does not produce any adverse reactions behaving similar to alumina [70].

Recent hip simulator studies show that self-mated silicon nitride couples exhibit up to 3 million cycles of wear compared to self-mated alumina; however, some self-mated silicon nitride couples show increased wear at the end of 5 million cycles compared to alumina $\mathrm{CoC}$ [71]. Further long term clinical studies of retrieved heads of silicon nitride and hip simulator studies by others may be necessary.

Hybrid Design of Oxide Ceramic Layer on metal (Oxinium ${ }^{\mathrm{TM}}$ ) A new zirconium alloy ( $\mathrm{Zr}-2.5 \mathrm{Nb})$ was introduced to hip arthroplasty in 2003 [68]. When heated in an air environment, the surface of the metal zirconium converts to a black zirconium oxide which is approximately 4 to $5 \mu \mathrm{m}$ thick $[60,72,73]$. This oxidized zirconium femoral head commercialized as Oxinium ${ }^{\text {тм }}$ (OxZr; Smith \& Nephew, Memphis, TN, USA) is not a coating, but a surface transformation by oxygen diffusion hardening process, which is expected to provide improved resistance under load bearing. It is a relatively new material used as an alternative to alumina or zirconia ceramics, demonstrating increased hardness and decreased surface roughness similar to zirconia, but possessing inherently high fracture toughness and fatigue strength because of the metal substrate [74].

In a simulator study, it was observed that Oxinium ${ }^{\mathrm{TM}}$ heads produced $45 \%$ less wear than did smooth Co-Cr heads, and, when the heads were roughened, the difference was much greater, with oxinium producing $61 \%$ less wear. Lewis et al. compared $50 \mathrm{Co}-\mathrm{Cr}$ and 50 oxinium heads and observed the clinical outcome to be equivalent at 2 years of follow-up [75].

Despite the clinical use of OxZr's head for more than eight years, we need more reliable data about long term outcomes.

\section{Ultra-hard coatings on metals}

While Co-Cr alloy in self-mated configuration or the alloy heads sliding against PE or XLPE are frequently used in THA, over $50 \%$ of failed artificial hipjoints are mainly due to osteolysis mediated aseptic loosening in addition to metal ion allergies overa long term period [76]. A frequent used alternative hybrid approach is to coat metal alloys with very hard, biocompatible surface layers such as diamond-like carbon (DLC, $5000 \mathrm{HV}$ ) [77] or titanium nitride (TiN $2100 \mathrm{HV}$ ) [78].

This approach ensures that the original properties of high strength metallic substrate are retained while: (a) supporting a bearing surface; and (b) avoiding the release of toxic metal ions from the underlying the Ti alloy substrate. However, there are several problems such as local delamination, crevice corrosion, third body wear [78, 79]. Another method is to deposit pure diamond on the metal head. In this regard, coating of ultra nanocrystalline diamond (UND) with grain size of 3-100 nm was directly applied to $\mathrm{Ti}$ and $\mathrm{Co}-\mathrm{Cr}$ alloy using microwave plasma CVD [80, 81]. UND coatings possess high hardness (56-80 GPa) and low surface roughness, high wear resistance to third-body wear particles [82]. Nevertheless, large compressive stresses are 
retained in the UND coating due to impurities at the grain boundaries, affecting the adhesion to the substrate [83]. In short, further enhancements to these coating techniques are needed to meet the high wear resistance, mechanical reliability and adhesive requirements for prolonged THA.

\section{Clinical aspects of bearing surface}

Bearing couples should have a low coefficient of friction, high surface hardness with lowductility and scratch resistance, and generate a low volume of wear particles. Moreover, surfaces exposed to tissues should be non-cytotoxic, biocompatible, and bioinert [84]. There are several bearing materials that are commonly used in clinical practice (Fig. 2).

\section{MoP articulation \\ Advantages}

MoP composed of a small metal ball and a cemented PE cup in 1963 [85]. Over the last few decades, one of the most acceptable bearing surface couple in a prosthetic hip is a Co-Cr femoral head articulating with a UHMWPE acetabular component in view of the excellent Long term results available. Tsukamoto $\mathrm{M}$ et al. reported that XLPE group presented a significantly reduced wear rate compared with the conventional PE group (XLPE groups, $0.035 \mathrm{~mm} / \mathrm{yr}$.; conventional PE group, $0.118 \mathrm{~mm} / \mathrm{yr}$ ) [86]. This bearing surface couple remains the one of the standards to which wear testing for other bearing articulations are compared. MoP bearing surface, a bearing surface with good long term results in elderly patients, once was taken as gold standard for THA [87].

\section{Disadvantages}

It became clear that PE liner wear debris generated with time was associated with the occurrence of osteolysis which leads to subsequent loosening and eventual implant failure (Fig. 3). This osteolysis appears tooccur more commonly at wear rates of more than $0.1 \mathrm{~mm} / \mathrm{yr}$. and is uncommon when wear rate is less than $0.05 \mathrm{~mm} /$ yr. $[88,89]$. It has been reported that the osteolysis rate of MoP is as high as $26 \%$, and aseptic loosening rate is $3 \%$ at 10 -year follow up [90].

During the past decade, different manufacturers have begun to develop new biomaterials in order to decrease PE wear, such as XLPE, Antioxidant Doped Polyethylene and PMPC. Brach et al. reported better performance by this newer XLPE than with conventional or even first-generation XLPE [91]. The other strategy is to introduce vitamin $\mathrm{E}$, the antioxidant alpha-tocopherol, into UHMWPE prior toconsolidation to help prevent the oxidative degradative reaction. This would avoid the deleterious effect of the melting process that decreases the mechanical properties of PE. Oral et al. reported good wear and improved mechanical and fatigue properties [92]. However, these new technology whose success and impact will be determined in the longer term. Analysis of retrieved components and clinical results will continue to inform us on the effects of wear problems [93].

\section{Wear mechanism}

Adhesive features have been found on the surface of PE cups matched with a metallic ball [94]. Welding between the cup and ball generates fibrils on the surface of the polymeric material. These fibrils may become torn off and pulled away as loose particles. Without sufficient lubrication, bigger fragments may be transferred from counterbody to body and vice versa. Such particles may introduce abrasion in the form of two or three body abrasion resulting in scratches on the surface.

\section{MoM articulation \\ Advantages}

Proposed advantages included the reduction in wear, improved range of movement and a lower dislocation rate $[95,96]$ and MoM bearings have wear rates that are 20 to 100 times lower than metal-on-conventional polyethylene [97]. MoM THA using a $28 \mathrm{~mm}$ head has shown favorable results compared with large head MoM THA. Small head MoM showed a relatively low rate of

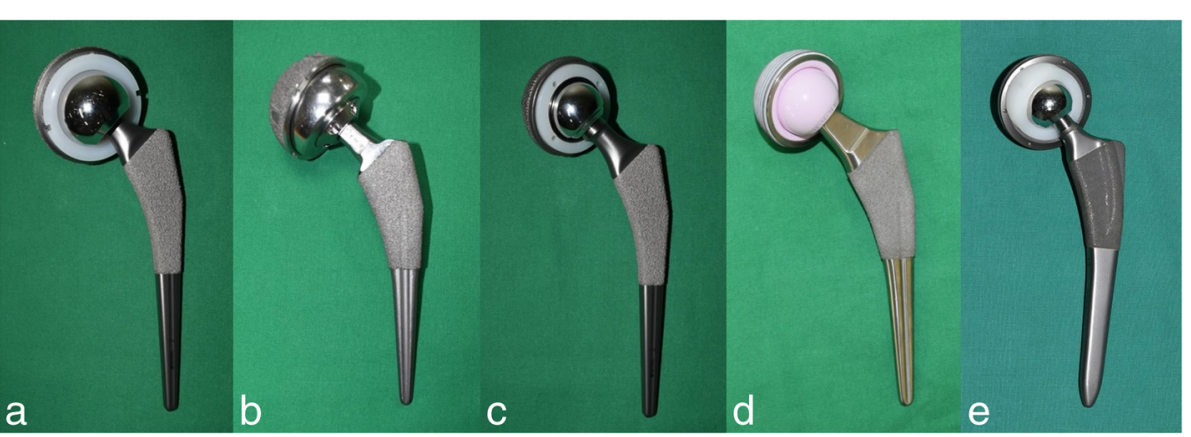

Fig. 2 Recent bearing materials used in THA (a) MoP bearing (b) Large head MoM bearing (c) Small head MoM bearing (d) CoC articulation (e) CoP articulation 


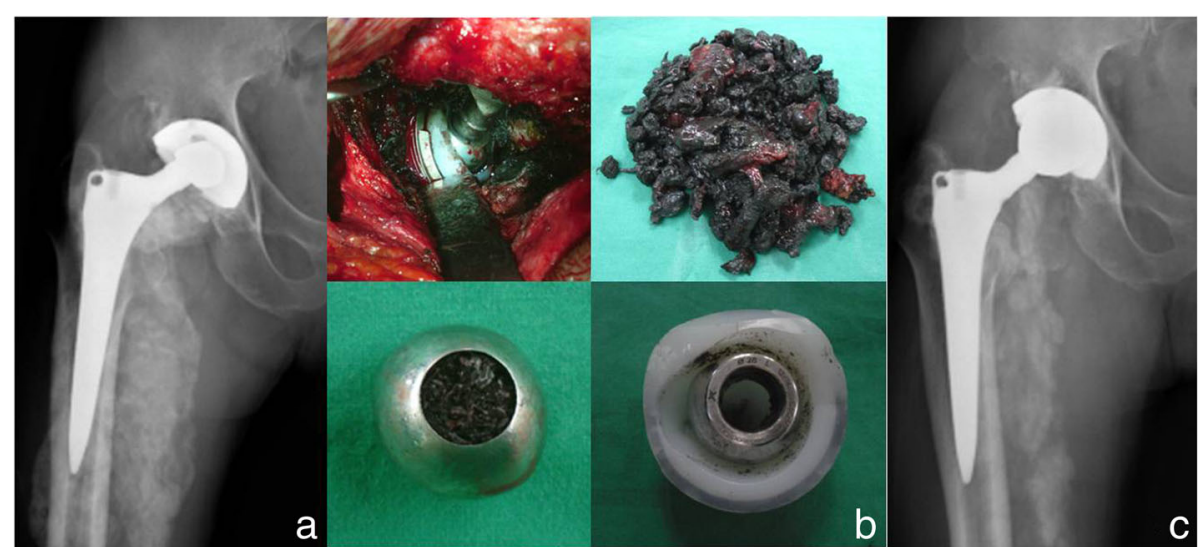

Fig. 3 A 62-year-old male patient with right total hip arthroplasty using MoP bearing (a) Radiograph illustrating liner wear and metalosis (b) Severe metalosis and osteolysis (c) Radiographs after revision surgery including excising mass, changing to metasul liner and metal head after cementing

aseptic loosening at a mean follow up of 20 years [98]. Yoon et al. reported that good clinical results with no complicationsin THAs with MoM bearing even with chronic renal failure [99]. Small head MoM bearing seems to have good results, relatively.

\section{Disadvantages}

The problems with large bead MoM began to appear in 2005. With increasing clinical experience, the national joint registries have recently reported the failure rate of THA with MoM bearings to be $2-3$ fold higher than contemporary THA with non MoM bearings $[100,101]$ associated with local bone and softtissue necrosis, with pseudotumor formation comprising a predominantly lymphocytic inflammatory reaction $[102,103]$ and, wear particles in the form of cobalt and chromium ions have been detected throughout the body [104]. Although granuloma have been found in both the liver and spleen [105] and increased chromosomal translocation has been found within lymphocytes [106], there is currently no hard evidence that this leads to neoplasia [107].

Furthermore, midterm studies demonstrated increased rates of osteolysis and implant.

Failure (Fig. 4), raising concerns about the longevity and safety of this bearing surface [108-110]. Korovessis et al. followed 217 patients who underwent a primary THA using a second-generation, large diameter MoM bearing surface for an average of 77 months [108]. During this follow up period, 14 THAs (6.5\%) were revised and found to have concerning signs of metallosis and lymphocytic infiltrates raising concerns about this bearing surface. Park et al. followed 169 hips who underwent THA using a second-generation MoM bearing surface for a minimum of 24 months and noted 10 hips (5.9\%) had early osteolysis [110]. The poor performance associated with large head MoM bearing surfaces led the Food and Drug Administration to remove several second-generation MoM THA systems from the market, effectively ushering out the era of this bearing surface [111].

\section{Wear mechanism}

The dominant wear mechanism is determined to be mild surface fatigue. Surface fatigue is introduced by direct solid contact of surface asperities or by foreign and/or system inherent third bodies, which repeatedly slide or roll within the wear track. Although these third bodies contribute to fatigue related wear loss, this wear is several orders of magnitude smaller than would be introduced by adhesion. Tribochemical reactions also comprise an important wear mechanism in MoM hip joints. They might be triggered by the synergistic interaction of wear and corrosion and can influence the tribosystem in a positive or negative manner.

\section{CoC articulation \\ Advantages}

In the late $60 \mathrm{~s}, \mathrm{CoC}$ bearings were first introducedin hip arthroplasty by Boutin [112]. They have undergone many generations of changes since then during which the susceptibility to fracture (a problem in early generation ceramics) has been overcome. Since ceramics are harder than metals, are biologically inert and have better lubrication properties leading to low wear rates [113], $\mathrm{CoC}$ bearings make an attractive choice for ensuring long term survival of hip prosthesis. The minimal wear particles released from $\mathrm{CoC}$ bearings are also biologically relatively inert and at nanometric size, significantly reducing the osteolysis produced due to PE wear particles. In addition, $\mathrm{CoC}$ bearing combination also has lesser coefficient of friction, higher wettability with biologically inert wear particles [114]. Clinical results have confirmed higher survivorship, lesser wear and low osteolysis making these bearings an excellent choice for young and active individuals [115]. Yoon et al. reported no case of 


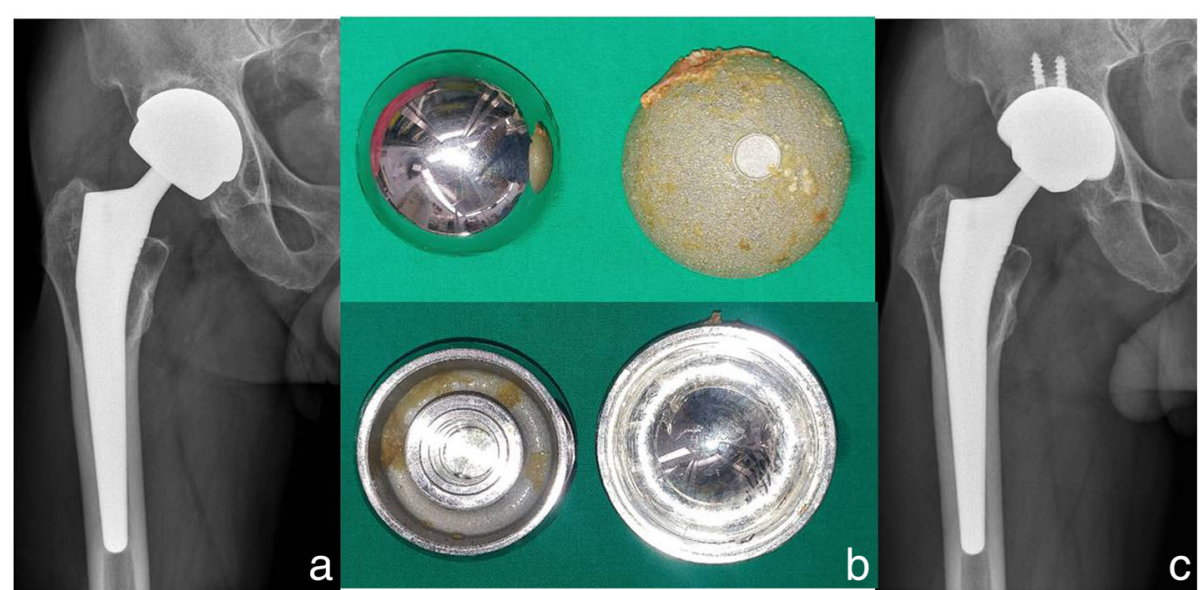

Fig. 4 A 68-year-old male patient with right total hip arthroplasty using large head MoM bearing (a) Preoperative radiograph of acetabular aseptic loosening (b) Large head MoM bearing (c) Radiographs after acetabular revision using CoC bearing

osteolysis after $3^{\text {rd }}$ generation of $\mathrm{CoC}$ bearing THA [116] and lower rate of osteolysis has been confirmed by many other studies $[117,118]$.

Hernigou et al. investigated wear and osteolysis in bilateral arthroplasties (one $\mathrm{CoC}$ and the contralateral $\mathrm{CoP}$ ) of patients who had survived 20 years without revision and without loosening of either hip [119]. The number of lesions was higher on the side with Cop couple. Hai-bo Si et al. reviewed several articles that wear rate was also lower in CoC than CoP THA [120].

$\mathrm{CoP}$ articulations also reportedly have reduced wear rates compared to metal heads on PE in THA [121].

\section{Disadvantages}

Though the ceramics are the new preferred bearing surface, especially in the young, they are not without their share of complications which include squeaking noises, stripe wear, a rare bearing surface fracture or chipping during insertion. Complications have been more commonly associated with acetabular component malposition (more vertical cups), smaller femoral heads and non-adherence to meticulous surgical technique [122, 123]. Fracture of a ceramic head and/or liner remains a major disadvantage for this bearing combination compared with MoP or MoM (Fig. 5). Earlier generations of alumina ceramic heads had a reported risk for fracture until 13.4\%, however for newer implants (Biolox Forte and Delta) the reported fracture rate is much lower at 0 to $3.2 \%[124,125]$.

Another concern remains squeaking of ceramic bearings. This potentially affects the patient's quality of lifeand survivorship of the implant due to revision of the squeaky hip. Noises emanating from ceramic bearings (usually clicking and squeaking) have been reported with rates that vary from 0 to $33 \%$. Fortunately clinically the problem is often minor in themajority of patients and revision surgery is indicated onlyoccasionally. Yoon et al. also reported low incidence of squeaking (1.5\%), and there were no complications to limit daily life and no revision [126]. Despite these shortcomings, $\mathrm{CoC}$ articulation seems to be the best recently.

\section{Wear mechanism}

The dominating wear mechanism is mild surface fatigue maintaining a polished appearance in most areas of the articulating surfaces. The grain structure of the material can be easily identified in such polished areas. Sometimes, fine scratches originating from the initial polishing procedure during manufacturing are still visible indicating a very mild wear process. Abrasive scratches can be observed, however to a much lower extent than in other systems. No tribochemical reaction layers have been reported.

\section{Ceramic on PE (CoP) articulation Advantages}

$\mathrm{CoP}$ as a bearing couple currently accounts for around one in seven hip replacements in the UK [127]. Potentially this keeps the advantages of the softer, less rigid PE surface and utilises the advantages of the smooth, hard ceramic surface.

Over the period examined, CoP bearing surfaces steadily increased in popularity to become the most popular bearing surface type. Although concerns about fracturing of the femoral head [128] and increased costs had decreased usage of ceramic heads in the 1980s and 1990s, the advent of large ceramic heads with low fracture rates, low wear rates, and multiple neck length options over the past decade had increased the use of CoP bearings [129].

It is also apparent from the literature that $\mathrm{CoC}$ hips have lower wear rates compared with CoP hips, however, the mid-term studies utilising newer alumina ceramic with newer PEs show no difference in osteolysis or patient satisfaction at five years [130]. 


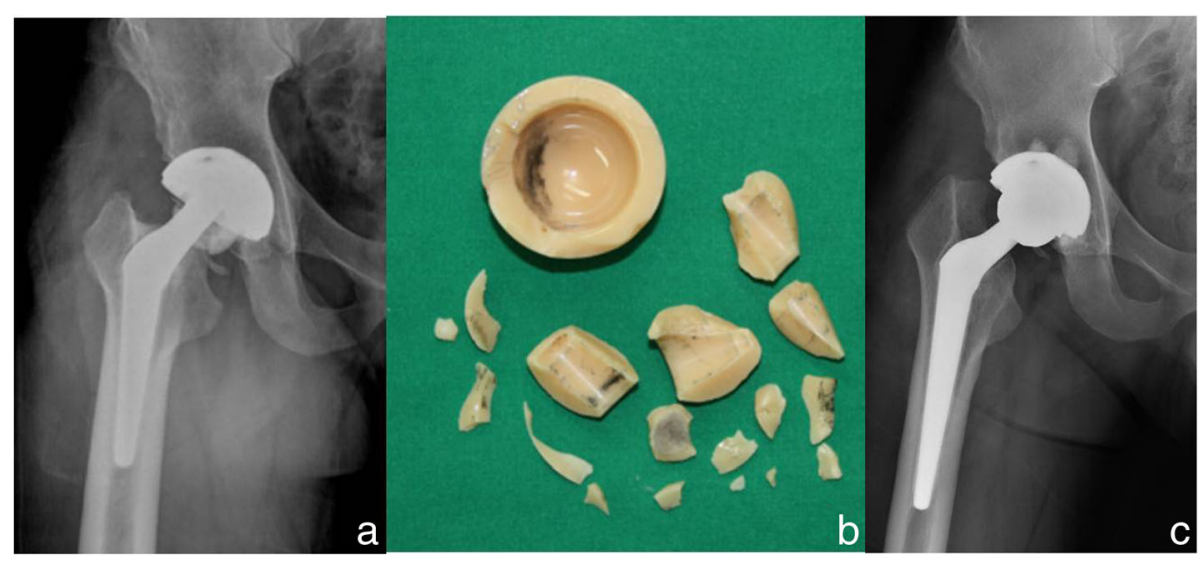

Fig. 5 A 34-year-old male patient with right total hip arthroplasty using CoC articulation (Forte) (a) Radiograph with fractured ceramic head and liner (b) The fractured ceramic head and liner (c) Radiographs after revision surgery changing the ceramic liner and fractured head to metasul liner and metal head after cementing

\section{Disadvantages}

Theoretically, the limitations of CoP bearing surfaces involves the risk of alumina head fracture, the resultant difficult revision surgery [131], metal transfer which can increase surface roughness, and third body wear leading to increased PE wear [132]. With the advent of delta ceramic, the rate of fracture decreased dramatically. There has been no reports yet, about the clinically significant problem coming from metal transfer (Table 1).

\section{Wear mechanism}

It may be similar to MoP articulation. Wear mechanism is surface fatigue where the PE part is usually by far more affected than the hard counterbody. Surface fatigue is associated with repetitive loading and generates wear features such as pitting and delamination [133, 134]. The most common wear appearance in PE cups is polishing.
Unlike in MoM articulation, no tribochemical reactions have yet been reported for polymer cups. But, this does not preclude their existence. PE transfer films on the hard counter parts have been reported [135].

\section{Orthopedic wear debris}

Wear debris is formed at prosthetic joint articulations, at modular interfaces, at areas of impingement, and at nonarticulating interfaces due to abrasion with the surrounding bone, or debris [136].

Cells in the periprosthetic environment are exposed to a continuous production of wear particles. The biologic response to particle wear debris complex and drives the process toward periprosthetic tissue destruction and implant loosening. Although most of the studies have focused on UHMWPE particles, particles generated from other sources may induce an inflammatory reaction and

Table 1 Advantages and disadvantages of bearing surfaces

\begin{tabular}{|c|c|c|}
\hline Bearing Surface & Advantages & Disadvantages \\
\hline \multirow[t]{3}{*}{ MoP Articulation } & Good long term results in elderly patients & Higher rate of liner wear \\
\hline & - Newly materials - XLPE, Antioxidant doped PE & - PE liner wear debris generated the occurrence of osteolysis \\
\hline & & - Newly materials do not have long term results \\
\hline \multirow[t]{4}{*}{ MoM Articulation } & . Reduction in wear & - Bone and soft tissue necrosis with pseudotumor formation \\
\hline & Improvement of range of movement & - Cobalt and chromium ions can affect the body \\
\hline & - Lower dislocation rate & - Relatively high rate of osteolysis and implant failure \\
\hline & - Good clinical results in small head MoM & - Withdrawal of large head MoM \\
\hline \multirow[t]{4}{*}{ CoC Articulation } & - Lower wear rate & - Ceramic fracture \\
\hline & - Lower osteolysis & Squeaking noise \\
\hline & - Very higher survivor rate in long term results & \\
\hline & - Harmless wear particle to human body & \\
\hline \multirow[t]{2}{*}{ CoP Articulation } & - Ceramic surfaces advantages + PE surfaces advantages & - Alumina head fracture \\
\hline & - Lower wear rate & - Metal transfer \\
\hline
\end{tabular}


subsequent osteolysis [137, 138]. For example, silicate and stainless steel particles, as possible containments from drilling and reaming tools, may elicit an aggressive cellular response. Although they may participate in initiating and/or instigating an inflammatory process, their role is considered minor. Alumina ceramic is a material commonly described as bio-inert [139]. However, submicron-sized particulates of alumina and zirconia may elicit a similar but less intense reaction to those seen with submicron-sized polymers and metal debris.

\section{Conclusion}

THA remains a highly successful procedure providing good pain relief and improvement of activity levels. Despiteits success, the expectations continue to increase with more and more young patients undergoing hip replacement and most of them seeking higher activity level (higher range ofmotion and stability in those ranges) as well as longevity of the prosthesis. Besides, the fixation method for the prosthesis, good surgical approach, bearing surfaces remain the most important determinant of longevity of the hip prosthesis.

Newer bearing surfaces incurrent clinical practice have shown promising clinical outcomes. With success of these wear reducing bearing surfaces, the scientific community will need to focus on not only further reducing abrasive wear but on reducing stress shielding as well by newer materials as well as designs. Ongoing research and the future of biomaterials in the hip are anticipated.

\section{Abbreviations \\ CoC: ceramic on ceramic; Co-Cr: cobalt-chromium; CoP: ceramic on polyethylene; DLC: diamond-like carbon; MoM: metal on metal; MoP: metal on polyethylene; PE: polyethylene; PMPC: poly (2-methacryloyloxyethyl phosphorylcholine); THA: total hip arthroplasty; TiN: titanium nitride; UHMWPE: ultra high molecular weight polyethylene; UND: ultra nanocrystalline diamond; XLPE: high crosslinked UHMWPE; ZTA: zirconia-toughened alumina}

\section{Authors' contributions}

Both authors read and approved the final manuscript.

Ethics approval and consent to participate

Not applicable.

\section{Consent for publication}

Not applicable.

\section{Competing interests}

The authors declare that they have no competing interests.

\section{Publisher's Note}

Springer Nature remains neutral with regard to jurisdictional claims in published maps and institutional affiliations.

Received: 21 June 2018 Accepted: 3 October 2018

Published online: 05 December 2018

\section{References}

1. National Joint Registry for England. Wales, Northern Ireland and the Isle of Man. 13th AnnualReport.http://www.njrcentre.org.uk/njrcentre/Portals/0/ Documents/England/Reports/13th\%20Annual\%20Report/
07950\%20NJR\%20Annual\%20Report\%202016\%200NLINE\%20REPORT.pdf. Accessed 2016.

2. Maradit Kremers H, Larson DR, Crowson CS, et al. Prevalence of TotalHip and knee replacement in the United States. J Bone Joint Surg Am. 2015;97: 1386-97. https://doi.org/10.2106/JBJS.N.01141.

3. Kurtz S, Ong K, Lau E, Mowat F, Halpern M. Projections of primary and revision hip and kneearthroplasty in the United States from 2005 to 2030 J Bone Joint Surg Am. 2007;89:780-5.

4. Health Insurance Review \& Assessment Service, Korea Healthcare Bigdata Hub. http://opendata.hira.or.kr/op/opc/olapDiagBhvInfo.do. Accessed 14 Sept 2018.

5. Miura K, Yamada N, Hanada S, Jung TK, Itoi E. The bone tissue compatibility of a new Ti-Nb-Sn alloywith a low Young's modulus. Acta Biomater. 2011;7:2320-6.

6. Guo S, Bao ZZ, Meng QK, Hu L, Zhao XQ. A novel metastable Ti-25Nb-2Mo4Sn alloy with high strength and low Young's modulus. Metall Mater Trans A Phys Metall Mater Sci. 2012:43:3447-51.

7. Niinomi M, Hattori T, Morikawa K, Kasuga T, Suzuki A, Fukui H, Niwa S. Development of lowrigidity beta-type titanium alloy for biomedical applications. Mater Trans. 2002;43:2970-7.

8. Okazaki Y. A new Ti-15Zr-4Nb-4Ta alloy for medical applications. Curr Opin Solid State Mater Sci. 2001:5:45-53.

9. Bai X, Sandukas S, Appleford MR, Ong JL, Rabiei A. Deposition and investigation of functionallygraded calcium phosphate coatings on titanium. Acta Biomater. 2009;5:3563-72.

10. Bai X, Sandukas S, Appleford MR, Ong JL, Rabiei A. Antibacterial effect and cytotoxicity of Ag-doped functionally graded hydroxyapatite coatings. J Biomed Mater Res Part B Appl Biomaterials. 2012;100:553-61.

11. Chen W, Liu Y, Courtney HS, Bettenga M, Agrawal CM, Bumgardner JD, Ong JL. In vitro anti-bacterial and biological properties of magnetron co-sputtered silver-containing hydroxyapatite coating. Biomaterials. 2006;27:5512-7

12. Ong JL, Lucas LC, Lacefield WR, Rigney ED. Structure solubility and bond strength of thin calcium-phosphate coatings produced by ion-beam sputter deposition. Biomaterials. 1992;13:249-54.

13. Yang $Y Z$, Kim KH, Ong JL. Review on calcium phosphate coatings produced using a sputtering process - an alternative to plasma spraying. Biomaterials. 2005;26:327-37.

14. Kim HM, Miyaji F, Kokubo T, Nakamura T. Preparation of bioactive Ti and its alloys via simple chemical surface treatment. J Biomed Mater Res. 1996;32:409-17.

15. Kim HM, Miyaji F, Kokubo T, Nishiguchi S, Nakamura T. Graded surface structure of bioactive titanium prepared by chemical treatment. J Biomed Mater Res. 1999;45:100-7.

16. Kim HM, Takadama H, Miyaji F, Kokubo T, Nishiguchi S, Nakamura T. Formation of bioactivefunctionally graded structure on Ti-6Al-4V alloy by chemical surface treatment. J Mater Sci Mater Med. 2000;11:555-9.

17. Kizuki T, Takadama H, Matsushita T, Nakamura T, Kokubo T. Preparation of bioactive Ti metal surface enriched with calcium ions by chemical treatment. Acta Biomater. 2010;6:2836-42.

18. Kokubo T, Pattanayak DK, Yamaguchi S, Takadama H, Matsushita T, Kawai T, Takemoto M, Fujibayashi S, Nakamura T. Positively charged bioactive Ti metal prepared by simple chemical and heat treatments. J R Soc Interface. 2010;7:503-13.

19. Oral E, Christensen SD, Malhi AS, Wannomae KK, Muratoglu OK. Wear resistance and mechanical properties of highly cross-linked, ultrahigh-molecular weight polyethylene doped with vitamin E. J Arthroplast. 2006;21:580-91.

20. Oral E, Muratoglu OK. Vitamin E diffused, highly crosslinked UHMWPE: a review. Int Orthop. 2011;35:215-23.

21. Kyomoto M, Moro T, Konno T, Takadama H, Yamawaki N, Kawaguchi H, Takatori Y, Nakamura K, Ishihara K. Enhanced wear resistance of modified cross-linked polyethylene by grafting with poly(2-methacryloyloxyethyl phosphorylcholine). J Biomed Mater Res Part A. 2007:82(1):10-7.

22. Kyomoto M, Moro T, Iwasaki Y, Miyaji F, Kawaguchi H, Takatori Y, Nakamura K, Ishihara K. Superlubricious surface mimicking articular cartilage by grafting poly(2-methacryloyloxyethyl phosphorylcholine) on orthopaedic metal bearings. J Biomed Mater Res Part A. 2009;91:730-41.

23. Clarke IC, Manaka M, Green DD, Williams P, Pezzotti G, Kim YH, Ries M, Sugano N, Sedel L, Delauney C, et al. Current status of zirconia used in total hip implants. J Bone Joint Surg Am. 2003:85:73-84.

24. Begand S, Oberbach T, Glien W. Investigations of the mechanical properties of an alumina toughened zirconia ceramic for an application in joint prostheses. Key Eng Mater. 2005;284:1019-22. 
25. Al-Hajjar M, Jennings LM, Begand S, Oberbach T, Delfosse D, Fisher J. Wear of novel ceramic-on-ceramic bearings under adverse and clinically relevant hip simulator conditions. J Biomed Mater Res Part B Appl Biomater. 2013; 101:1456-62.

26. Hobbs LW, Rosen VB, Mangin SP, Treska M, Hunter G. Oxidation microstructures and interfaces in the oxidized zirconium knee. Int J Appl Ceram Technol. 2005;2:221-46.

27. Good V, Ries M, Barrack RL, Widding K, Hunter G, Heuer D. Reduced wear with oxidized zirconium femoral heads. J Bone Joint Surg Am. 2003;85:105-10.

28. Burger W, Richter HG. High strength and toughness alumina matrix composites by transformationtoughening and 'in situ' platelet reinforcement (ZPTA) - the new generation of bioceramics. Key Eng Mater. 2000;192-5:545-8.

29. McKee GK, Watson-Farrar J. Replacement of arthritic hips by the McKeeFarrar prosthesis. J Bone Joint Surg Br. 1966;48(2):245-59.

30. Triclot P. Metal-on-metal: history, state of the art. Int Orthop. 2011;35(2):201-6.

31. Learmonth ID, Young C, Rorabeck C. The operation of the century: total hip replacement. Lancet. 2007;370:1508-19. https://doi.org/10.1016/S01406736(07)60457-7.

32. Berry DJ, Harmsen WS, Cabanela ME, Morrey BF. Twenty-five-year survivorship of two thousand consecutive primary Charnley total hip replacements: factors affecting survivorship of acetabular and femoral components. J Bone Joint Surg Am. 2002;84-A:171-7.

33. Boutin P. Total arthroplasty of the hip by fritted alumina prosthesis. Experimental study and 1st clinical applications. Orthop Traumatol Surg Res. 2014;100:15-21.

34. Howmedica I. Strength for Life : The Vitallium Alloy Story. Rutherord: Howmedica Inc:; 1995.

35. Bronzino JD. The Biomedical Engineering Handbook. 2nd ed: CRC Press; 1999.

36. Head WC, Bauk DJ, Emerson RH. Titanium as the material of choice for cementless femoral components in total hip arthroplasty. Clin Orthop Relat Res. 1995;311:85-90.

37. Branemark PI, George AZ, Tomas A. Tissue-integrated prostheses: osseointegration in clinical dentistry. Chicago: Quintessence: 1985. p. 1-76.

38. Landor I, Vavrik P, Sosna A, Jahoda D, Hahn H, Daniel M. Hydroxyapatite porous coating and the osteointegration of the total hip replacement. Arch Orthop Trauma Surg. 2007;127(2):81-9.

39. Balla VK, Bodhak S, Bose S, Bandyopadhyay A. Porous tantalum structures for bone implants: fabrication, mechanical and in vitrobiological properties. Acta Biomater. 2010;6(8):3349-59.

40. Matassi F, Botti A, Sirleo L, Carulli C, Innocenti M. Porous metal for orthopedics implants. Clin Cases Miner Bone Metab. 2013;10(2):111-5.

41. Charnley J. Arthroplasty of the hip: a new operation. Lancet. 1961;1:1129-32.

42. Hopper RH Jr, Young AM, Orishimo KF, Engh CA Jr. Effect of terminal sterilization with gas plasma or gammaradiation on wear of polyethylene liners. J Bone Joint Surg Am 2003;85:464-468.

43. McKellop H, Shen FW, Lu B, Campbell P, Salovey R. Effect of sterilization method and other modifications on the wearresistance of acetabular cups made of ultra-high molecular weightpolyethylene. A hip-simulator study. J Bone Joint Surg Am. 2000;82:1708-25.

44. Devane PA, Horne JG, Martin K, Coldham G, Krause B. Three-dimensional polyethylene wear of a press-fit titaniumprosthesis. Factors influencing generation of polyethylene debris. J Arthroplasty. 1997;12:256-66.

45. Young AM, Sychterz CJ, Hopper RH Jr, Engh CA. Effectof acetabular modularity on polyethylene wear and osteolysis intotal hip arthroplasty. J Bone Joint Surg Am 2002; 84:58-63.

46. Harris WH. The problem is osteolysis. Clin Orthop Relat Res. 1995;311:46-53.

47. Kim YH, Kim JS, Park JW, Joo JH. Periacetabular osteolysis is the problem in contemporary total hip arthroplasty in young patients. J Arthroplast. 2012; 27:74-81.

48. Digas G, Kärrholm J, Thanner J, Malchau H, Herberts P. Highly cross-linked polyethylene in total hip arthroplasty: randomizedevaluation of penetration rate in cemented and uncementedsockets using radiostereometric analysis. Clin Orthop Relat Res. 2004;429:6-16.

49. Manning DW, Chiang PP, Martell JM, et al. In vivo comparative wear study of traditional and highly cross-linked polyethylene in total hip arthroplasty. J Arthroplast. 2005;20(7):880-6.

50. Martell JM, Verner JJ, Incavo SJ. Clinical performance of a highly cross-linked polyethylene at two years in total hip arthroplasty: a randomized prospective trial. J Arthroplast. 2003;18(7 suppl 1):55-9.
51. Collier JP, Currier BH, Kennedy FE, et al. Comparison of cross-linked polyethylene materials for orthopaedic applications. Clin Orthop Relat Res. 2003;414:289-304

52. Muratoglu OK, Bragdon CR, O'Connor DO, et al. Unified wear model for highly cross-linked ultra-high molecular weight polyethylenes (UHMWPE). Biomaterials. 1999;20(16):1463-70.

53. Chiesa R, Tanzi MC, Alfonsi S, et al. Enhanced wear performance of highly crosslinked UHMWPE for artificial joints. J Biomed Mater Res. 2000;50(3):381-7.

54. Muratoglu OK, Greenbaum ES, Bragdon CR, et al. Surface analysis of early retrieved acetabular polyethylene liners: A comparison of conventional and highly crosslinked polyethylene. J Arthroplasty. 2004;19(1):68-77.

55. Dumbleton JH, D'Antonio JA, Manley MT, Capello WN, Wang A. The basis for a second-generation highly cross-linked UHMWPE. Clin Orthop Relat Res. 2006;453:265-71.

56. Ishihara K. Highly lubricated polymer interfaces for advanced artificial hip joints through biomimetic design. Polym J. 2015;47:585-97.

57. Hannouche D, Hamadouche M, Nizard R, et al. Ceramics in total hip replacement. Clin Orthop Relat Res. 2005;430:62-71.

58. Clarke IC, Good V, Williams P, Schroeder D, Anissian L, Stark A, Oonishi H, Schuldies J, Gustafson G. Ultra-low wear rates for rigid-on-rigid bearings in total hip replacements. Proc Inst Mech Eng H. 2000;214:331-47.

59. Jeffers JR, Walter WL. Ceramic-on-ceramic bearings in hip arthroplasty: state of the art and the future. J Bone Joint Surg Br. 2012;94(6):735-45.

60. Kurtz SM. UHMWPE Biomaterials Handbook. 2nd ed. Boston, mass: Academic Press; 2009.

61. Masonis JL, Bourne RB, Ries MD, et al. Zirconia femoral head fractures: A clinical and retrieval analysis. J Arthroplasty. 2004;19(7):898-905.

62. De Aza AH, Chevalier J, Fantozzi G, et al. Crack growth resistance of alumina, zirconia and zirconia toughened alumina ceramics for joint prostheses. Biomaterials. 2002;23(3):937-45.

63. Allain J, Le Mouel S, Goutallier D, et al. Poor eight-year survival of cemented zirconia-polyethylene total hip replacements. J bone Joint Surg Br. 1999; 81(5):835-42.

64. Masonis JL, Bourne RB, Ries MD, McCalden RW, Salehi A, Kelman DC. Zirconia femoral head fractures: a clinical and retrieval analysis. J Arthroplast. 2004;19:898-905.

65. Santos EM, Vohra S, Catledge SA, McClenny MD, Lemons J, Moore KD. Examination of surface and material properties of explantedzirconia femoral heads. J Arthroplast. 2004;19(7Suppl 2):30-4.

66. Chevalier J. What future for zirconia as a biomechanical? Biomaterials. 2006: 27(4):535-43.

67. Bal BS, Rahaman MN. Orthopedic applications of silicon nitride ceramics. Acta Biomater. 2012:8:2889-98.

68. McEntire BJ, Bal BS, Rahaman MN, Chevalier J, Pezzotti G. Ceramics and ceramic coatings in orthopaedics. J Eur Ceram Soc. 2015;35:4327-69.

69. Chen FC, Ardell AJ. Fracture toughness of ceramics and semi-brittle alloys using a miniaturized disk-bend test. Mater Res Innov. 2000;3:250-62

70. Bal BS, et al. Fabrication and testing of silicon nitride bearingsin total hip arthroplasty. J Arthroplast. 2009;24(1):110-6.

71. McEntire BJ, Lakshminarayanan R, Ray DA, Clarke IC, Puppulin L, Pezzotti G. Silicon nitride bearings for total joint arthroplasty. Lubricants. 2016;4:35.

72. Tribe H, Malek S, Stammers J, et al. Advanced wear of an Oxinium ${ }^{\text {TM }}$ femoral head implant following polyethylene liner dislocation. Ann R Coll Surg Engl. 2013;95(8):133-5.

73. Hernigou P, Mathieu G, Poingnard A, et al. Oxinium, a new alternative femoral bearing surface option for hip replacement. Eur J Orthop Surg Traumatol. 2007;17(3):243-6.

74. Kop AM, Whitewood C, Johnston DJ. Damage of Oxinium femoral heads subsequent to hip arthroplasty dislocation: Three retrieval case studies. J Arthroplasty. 2007;22(5):775-9.

75. Lewis PM, Moore CA, Olsen M, Schemitsch E, Waddell JP. Comparison of mid-term clinical outcomes following primarytotal hip arthroplasty with Oxinium versus cobalt chromefemoral heads. Orthopedics. 2008; 31(12Supppl2).

76. Abu-Amer Y, Darwech I, Clohisy JC. Aseptic loosening of total joint replacements: mechanisms underlying osteolysis and potential therapies. Arthritis Res Ther. 2007;9:S6.

77. Narayan RJ. Nanostructured diamondlike carbon thin films for medical applications. Mater Sci Eng C. 2005;25:405-16.

78. Pappas MJ, Makris G, Buechel FF. Titanium nitride ceramic film against polyethylene: A 48-million cycle wear test. Clin Orthop Relat Res. 1995;317:64-70. 
79. Hauert R, Falub CV, Thorwarth G, Thorwarth K, Affolter C, Stiefel M, Podleska LE, Taeger $G$. Retrospective lifetime estimation of failed and explanted diamond-like carbon coated hip joint balls. Acta Biomater. 2012:8:3170-6.

80. Catledge SA, Vohra YK. Effect of nitrogen addition on the microstructure and mechanical properties of diamond films grown using high-methane concentrations. J Appl Phys. 1999;86:698-700.

81. Catledge SA, Vaid R, Diggins P, Weimer JJ, Koopman M, Vohra YK. Improved adhesion of ultra-hard carbon films on cobalt-chromium orthopaedic implant alloy. J Mater Sci Mater Med. 2011;22:307-16.

82. Papo MJ, Catledge SA, Vohra YK. Mechanical wear behavior of nanocrystalline and multilayer diamond coatings on temporomandibular joint implants. J Mater Sci Mater Med. 2004;15:773-7.

83. Vila M, Amaral M, Oliveira FJ, Silva RF, Fernandes AJS, Soares MR. Residual stress minimum in nanocrystalline diamond films. Appl Phys Lett. 2006;89:093109.

84. Kumar N, Arora GN, Datta B. Bearing surfaces in hip replacement-evolution and likely future. Med J Armed Forces India. 2014;70(4):371-6.

85. Charnley J, Kamangar A, Longfield MD. The optimum size of prosthetic heads in relation to wear of plastic sockets in total replacement of hip. Med Biol Eng. 1969;7:31-9.

86. Tsukamoto M, Mori T, Ohnishi H, Uchida S, Sakai A. Highly cross-linked polyethylene reduces Osteolysis incidence and Wear-related reoperation rate in Cementless Total hip arthroplasty compared with conventional polyethylene at a mean 12-year follow-up. J Arthroplast. 2017;32(12):3771-6. https://doi.org/10.1016/j.arth.2017.06.047.

87. Vendittoli PA, Riviere C, Lavigne M, Lavoie P, Alghamdi A, Duval N. Aluminaon alumina versus metal on conventional polyethylene: a randomizedclinical trial with 9 to 15 years follow-up. Acta Orthop Belg. 2013;79:181-90.

88. Green TR, Fisher J, Stone M, Wroblewski BM, Ingham E. Polyethylene particles of a 'critical size' are necessary for theinduction of cytokines by macrophages in vitro. Biomaterials. 1998;19:2297-302.

89. Dumbleton JH, Manley MT, Edidin AA. A literature review ofthe association between wear rate and osteolysis in total hiparthroplasty. J Arthroplast. 2002;17:649-61.

90. D'Antonio JA, Capello WN, Naughton M. Ceramic bearings for total hiparthroplasty have high survivorship at 10 years. Clin Orthop Relat Res. 2012;470:373-81.

91. Brach del Prever EM, Bistolfi A, Bracco P, Costa L. UHMWPE for arthroplasty: past or future? J Orthop Traumatol. 2009;10:1-8.

92. Oral E, Christensen SD, Malhi AS, Wannomae KK. MuratogluOK. Wear resistance and mechanical properties of highlycross-linked, ultrahighmolecular weight polyethylene dopedwith vitamin E. J Arthroplast. 2006;21: 580-91.

93. Bragdon CR, Doerner M, Martell J, Jarrett B, Palm H, Malchau H. The 2012 John Charnley award: clinical multicenter studies of the wear performance of highly crosslinked remelted polyethylene in THA. Clin Orthop Relat Res. 2013;471:393-402.

94. McKellop HA, Campbell P, Park SH, Schmalzried TP, Grigoris P, Amstutz HC, Sarmiento A. The origin of submicron polyethylene wear debris in total hip arthroplasty. Clin Orthop Relat Res. 1995;311:3-20.

95. McMinn D, Daniel J. History and modern concepts in surface replacement. Proc Inst Mech EngH. 2006;220:239-51.

96. Daniel J, Pynsent PB, McMinn DJ. Metal-on-metal resurfacing of the hip inpatients under the age of 55 years with osteoarthritis. J Bone Joint Surg Br. 2004;86:177-84

97. Mauricio S, Christian H, Thomas P. Metal-on-Metal Total Hip Replacement. Clin Orthop Relate Res. 2005;430:53-61.

98. Moon JK, Kim Y, Hwang KT, Yang JH, Oh YH, Kim YH. Long-term outcomes after metal-on-metal Total hip arthroplasty with a 28-mm head: a 17- to 23year follow-up study of a previous report. J Arthroplast. 2018. https://doi. org/10.1016/j.arth.2018.02.089.

99. Hur Cl, Yoon TR, Cho SG, Song EK, Seon JK. Serum ion level after metal-onmetal THA in patients with renal failure. Clin Orthop Relat Res. 2008;466(3): 696-9. https://doi.org/10.1007/s11999-007-0093-3.

100. National Joint Registry for England. Wales, Northern Ireland and the Isle of Man. 5th Annual Report. http://www.njrcentre.org.uk/njrcentre/Portals/0/ Documents/England/Reports/5th\%20Annual.pdf. Accessed 2008.

101. Australian Orthopaedic Association National Joint Replacement Registry Annual Report. https://aoanjrr.sahmri.com/documents/10180/42662/ Annual\%20Report\%202008?version=1.1\&t=1349406277970. Asscessed 2008.
102. Willert HG, Buchhorn GH, Fayyazi A, et al. Metal-on-metal bearings and hypersensitivity in patients with artificial hip joints. A clinical and histomorphologicalstudy. J Bone Joint Surg Am. 2005;87:28-36.

103. Jacobs JJ, Hallab NJ. Loosening and osteolysis associated with metal-onmetalbearings: a local effect of metal hypersensitivity? J Bone Joint Surg Am. 2006:88:1171-2.

104. Brodner W, Bitzan P, Meisinger V, Kaider A, Gottsauner-Wolf F, Kotz R. Elevated serum cobalt with metal-on-metal articulating surfaces. J Bone Joint Surg Br. 1997;79(2):316-21.

105. Urban RM, Jacobs JJ, Tomlinson MJ, Gavrilovic J, Black J, Peoc'h M. Dissemination of wear particles to the liver, spleen, and abdominal lymph nodes of patients with hip or knee replacement. J Bone Joint Surg Am. 2000;82:457-76.

106. Case CP. Chromosomal changes after surgery for joint replacement. J Bone Joint Surg Br. 2001;83(8):1093-5.

107. Smith AJ, Dieppe P, Porter M, Blom AW. National Joint Registry of England and Wales Risk of cancer in first seven years after metal-on-metal hip replacement compared with other bearings and general population: linkage study between the National Joint Registry of England and Wales and hospital episode statistics. BMJ. 2012;344:e2383.

108. Korovessis P, Petsinis $G$, Repanti M, Repantis T. Metallosis after contemporarymetal-on-metal total hip arthroplasty. Five to nine-year followup. J BoneJoint Surg Am. 2006;88:1183-91.

109. Milosev I, Trebse R, Kovac S, Cor A, Pisot V. Survivorship and retrieval analysisof Sikomet metal-on-metal total hip replacements at a mean of seven years. J Bone Joint Surg Am. 2006;88:1173-82. https://doi.org/10. 2106/JBJS.E.00604.

110. Park YS, Moon YW, Lim SJ, Yang JM, Ahn G, Choi YL. Early osteolysisfollowing second-generation metal-on-metal hip replacement. J Bone Joint Surg Am. 2005;87:1515-21. https://doi.org/10.2106/JBJS.D.02641.

111. Administration FAD. List of Device Recalls. ... fda. gov/medicaldevices/ safety/ListofRecalls/default ...; 2014; https://www.accessdata.fda.gov/scripts/ cdrh/cfdocs/cfRES/res.cfm?start_search=1\&event_id=\&productdescription txt=hip\%20arthroplasty\&productcode=\&IVDProducts=\&rootCauseText= \&recallstatus=לerclassificationtypetext=\&recallnumber=\&postdatefrom= \&postdateto $=\&$ productshortreasontxt $=\&$ knumber $=\& P A G E N U M=500$. Accessed 06 Feb 2018

112. Boutin P. Total arthroplasty of the hip by fritted aluminum prosthesis. Experimental study and 1st clinical applications. Rev Chir Orthop Reparatrice Appar Mot. 1972;58:229-46.

113. Jonathan PG. Ceramic hip replacement history. Semin Arthroplast. 2011; 22(4):214-7.

114. Kurtz SM, Ong K. Contemporary total hip arthroplasty: Hard-on hard bearings and highly crosslinked UHMWPE. In: Kurtz SM, editor. UHMWPE Biomaterials Handbook. 2nd ed. Burlington: Academic(Elsevier); 2009. p. 55-79.

115. Williams S, Schepers A, Isaac G, Hardaker C, Ingham E, van der Jagt D, Breckon A, Fisher J. The 2007 Otto Aufranc award. Ceramic-on-metalhip arthroplasties: a comparative in vitro and in vivo study. Clin Orthop Relat Res. 2007:465:23-32.

116. Park KS, Seon JK, Yoon TR. The survival analysis in third-generation ceramicon-ceramic Total hip arthroplasty. J Arthroplast. 2015;30(11):1976-80. https:// doi.org/10.1016/j.arth.2015.05.017.

117. Lewis PM, Al-Belooshi A, Olsen M, Schemitch EH, Waddell JP. Prospective randomized trial comparing alumina ceramic-on-ceramic with ceramic-onconventional polyethylene bearings in total hip arthroplasty. J Arthroplasty. 2010;25(3):392-7.

118. Kubo T, Sawada K, Hirakawa K, Shimizu C, Takamatsu T, Hirasawa Y. Histiocyte reaction in rabbit femurs to UHMWPE, metal, and ceramicparticles in different sizes. J Biomed Mater Res. 1999;45(4):363-9.

119. Hernigou P, Zilber S, Filippini P, Poignard A. Ceramic-ceramic bearing decreases osteolysis: a 20-year study versus ceramic-polyethylene on the contralateral hip. Clin Orthop Relat Res. 2009;467:2274-80.

120. Si HB, Zeng Y, Cao F, Pei FX, Shen B. Is a ceramic-on-ceramic bearing really superiorto ceramic-on-polyethylene for primary total hiparthroplasty? A systematic review and meta-analysisof randomised controlled trials. Hip Int. 2015;25(3):191-8. https://doi.org/10.5301/hipint.5000223.

121. Glaser D, Komistek RD, Cates HE, Mahfouz MR. Clicking and squeaking:in vivo correlation of sound and separation for different bearingsurfaces. J Bone Joint Surg Am. 2008;90(Suppl(4):112-20.

122. Yang CC, Kim RH, Dennis DA. The squeaking hip: a cause for concerndisagrees. Orthopedics. 2007;30:739. 
123. Ranawat AS, Ranawat CS. The squeaking hip: a cause for concern-agrees. Orthopedics. 2007;30:738

124. Lusty PJ, Tai CC, Sew-Hoy RP, Walter WL, Walter WK, Zicat BA. Thirdgeneration alumina-on-alumina ceramic bearings incementless total hip arthroplasty. J Bone Joint Surg Am. 2007;89:2676-83.

125. Hamilton WG, McAuley JP, Dennis DA, Murphy JA, Blumenfeld TJ, Politi J. THA with Delta ceramic on ceramic: results of a multicenter investigational device exemption trial. Clin Orthop Relat Res. 2010;468:358-66.

126. Haq RU, Park KS, Seon JK, Yoon TR. Squeaking after third-generation ceramic-on-ceramic total hip arthroplasty. J Arthroplast. 2012;27(6):909-15. https://doi.org/10.1016/j.arth.2011.10.001.

127. Lancaster JG, Dowson D, Isaac GH, Fisher J. The wear of ultra-high molecular weight polyethylene sliding on metallic and ceramic counterfaces representative of current femoral surfaces in joint replacement. Proc Inst Mech Eng H. 1997:211(1):17-24.

128. Callaway GH, Flynn W, Ranawat CS, Sculco TP. Fracture of the femoral headafter ceramic-on-polyethylene total hip arthroplasty. J Arthroplast. 1995;10:855-9

129. Lehil MS, Bozic KJ. Trends in total hip arthroplasty implant utilization in theUnited states. J Arthroplast. 2014;29:1915-8. https://doi.org/10.1016/j.arth. 2014.05.017.

130. Rieger W. Ceramics in orthopaedics - 30 years of evolution and experience. In: Reiker CB, Oberholzer S, Wyss U, editors. World tribology forum in arthroplasty. Berne: Hans Huber Verlag; 2001.

131. Heisel C, Silva M, Schmalzried TP. Bearing surface options fortotal hip replacement in young patients. Instr Course Lect. 2004;53:49-65.

132. Della Valle AG, Doty S, Gradl G, Labissiere A, Nestor BJ. Wear ofa highly cross-linked polyethylene liner associated with metallicdeposition on a ceramic femoral head. J Arthroplast. 2004;19(4):532-6.

133. Magnissalis EA, Eliades $G$, Eliades T. Multitechnique characterization of articular surfaces of retrieved ultrahigh molecular weight polyethylene acetabular socket. J Biomed Mater Res. 1999;48(3):365-73.

134. Collier JP, Bargmann LS, Currier BH, Mayor MB, Currier JH, Bargmann BC. An analysis of hylamer and polyethylene bearings from retrieved acetabular components. Orthopedics. 1998;21(8):865-71.

135. Crockett R, Roba M, Naka M, Gasser B, Delfosse D, Frauchiger V, Spencer ND. Friction, lubrication, and polymer transfer between UHMWPE and CoCrMo hip-implant materials: a fluorescence microscopy study. J Biomed Mater Res A. 2009;89(4):1011-8.

136. McKellop HA. The lexicon of polyethylene wear in artificial joints. Biomaterials. 2007;28(34):5049-57.

137. Berger RA, Jacobs JJ, Quigley LR, Rosenberg AG, Galante JO. Primary cementless acetabular reconstruction in patients younger than 50 years old. 7- to 11-year results. Clin Orthop Relat Res. 1997;344:216-226.

138. Devane PA, Bourne RB, Rorabeck CH, MacDonald S, Robinson EJ. Measurement of polyethylene wear in metal-backed acetabular cups. II Clinical application. Clin Orthop Relat Res. 1995;319:317-26.

139. Lusty PJ, Tai CC, Sew-Hoy RP, Walter WL, Walter WK, Zicat BA. Thirdgeneration alumina-on-alumina ceramic bearings in cementless total hip arthroplasty. J Bone Joint Surg Am. 2007:89:2676-83.

Ready to submit your research? Choose BMC and benefit from:

- fast, convenient online submission

- thorough peer review by experienced researchers in your field

- rapid publication on acceptance

- support for research data, including large and complex data types

- gold Open Access which fosters wider collaboration and increased citations

- maximum visibility for your research: over $100 \mathrm{M}$ website views per year

At $\mathrm{BMC}$, research is always in progress.

Learn more biomedcentral.com/submissions 